\title{
Jerusalem and the Bar Kokhba Revolt Again: A Note
}

\author{
Eran Almagor
}

\begin{abstract}
This note examines again the overall significance of Jerusalem within the Bar Kokhba revolt. It does so firstly by suggesting a better way to read our texts: Cassius Dio (69.12.1-4) wrote in a partially thematic way, and Eusebius (HE 4.6.1-4) merged several sources together, so that there is no real difference between the two texts in terms of the sequence of the revolt and the establishment of the colony Aelia Capitolina. Secondly, the examination of other sources, different types of evidence and several traditions, may suggest that the Roman reconstruction works in the city did not finish before the revolt, but in fact were halted by it, even without assuming that the rebels actually controlled Jerusalem.
\end{abstract}

Keywords: Bar Kokhba, Jerusalem, Aelia Capitolina, Hadrian, Cassius Dio, Eusebius, Epiphanius, Pausanias, Appian, numismatics.

The recent (May 2018) find of another coin of the time of the revolt of Bar Kokhba (ben Kosiba), this time in a karst cave near the village Qibya, $30 \mathrm{~km}$ northwest of Ramallah, with the legend "for the freedom of Jerusalem" (לחר] [ות ירו]שלם) on its reverse, ${ }^{1}$ minted between the third and fourth year of the revolt (134/135-135/136 AD), and brought to that cave by Jewish rebels who found refuge in it, provides us with another opportunity to raise the question of the significance of Jerusalem during that revolt. The present note proposes points for a reassessment of the evidence and of the known problems.

As is known, the rebellion may have been sparked by Hadrian's decision to establish a colony in Jerusalem (Aelia Capitolina) and to erect a temple to Jupiter in it. This is at least what is said by the historian Cassius Dio (69.12.1-2), according to the epitome made by the eleventh century monk Xiphilinus:

At Jerusalem he founded a city in place of the one which had been razed to ground, naming it Aelia Capitolina, and on the site of the temple of the God he raised a new temple to Jupiter. This brought on a war of no slight importance nor of brief duration. For the Jews deemed it intolerable

${ }^{1}$ https://www.jpost.com/Israel-News/Rare-coin-from-ancient-Jewish-Bar-Kokhba-revolt-discoveredin-cave-553384 (accessed: September 2019). 
that foreign races should be settled in their city and foreign religious rites planted there (trans. E. Cary, LCL). ${ }^{2}$

If this narrative is correct, then Jerusalem played a prominent part in the revolt from its inception, and the rebellion was largely a religious struggle against the pagan temple and city in Jerusalem. According to Eusebius ( $H E$ 4.6.4), however, it would appear that the establishment of the colony was on the contrary the result of the revolt, seemingly as part of punitive measures:

Thus, when the city came to be bereft of the nation of the Jews, and its ancient inhabitants had completely perished, it was colonized by foreigners, and the Roman city that afterwards arose changed its name and in honour of the reigning emperor, Aelius Hadrian, was called Aelia (trans. K. Lake, LCL). ${ }^{3}$

Famously, scholars have debated this thorny question: who is correct, Cassius Dio or Eusebius? ${ }^{4}$ I would like to ask: is there really a difference between Cassius Dio and the account employed by Eusebius? We can see that Eusebius is merging three different sources at this point in the Ecclesiastical History. One is acknowledged as the author Ariston of Pella ( $H E$ 4.6.3), who presumably is the source for the entire account $H E$ 4.6.1-3 (which Felix Jacoby has set as FGrH 201 F 1). ${ }^{5}$ This section relates the revolt, the brutal reaction of the governor Rufus (Quintus Tineius Rufus), the identity of the Jewish leader Bar Chochebas (= Kokhba), the culmination and end of the revolt in Beththera (= Betar) and Hadrian's command to expel all Jews from Jerusalem and the district around it. Then, it would appear, Eusebius turns to another source. This text's account had the following sequence: (a) the city came to be bereft of the nation of Jews,

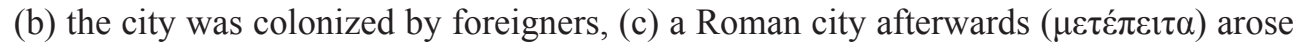
with the name Aelia in honour of Hadrian.

One may conjecture a transition between sources because of several considerations: the mention of Ariston at the end of section $H E$ 4.6.1-3 appears to signal an end to the employment of that source; the mention of the Jews' absence from Jerusalem is repeated in 4.6.4 in a way that may indicate the beginning of the use of a second source; and the sequence of $H E$ 4.6.4 is the reverse one from that of 4.6.3: first Jerusalem is deprived of Jews and then Hadrian is mentioned. The last point deserves a special consideration. The order of the events in 4.6.4 in fact depicts a very concise history of circumstances from $70 \mathrm{AD}$ onward. After the destruction of the Temple and Jerusalem, the city was emptied of Jews. ${ }^{6}$ It came to be occupied by foreigners, chiefly the Roman Legio X Fretensis and

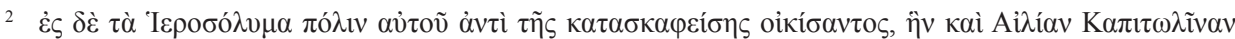

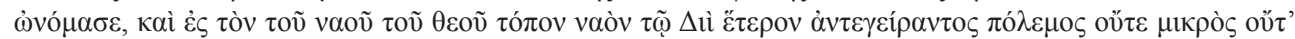

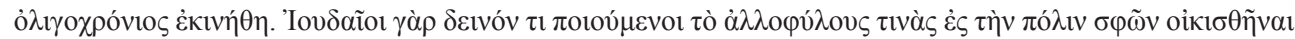

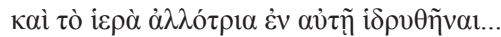

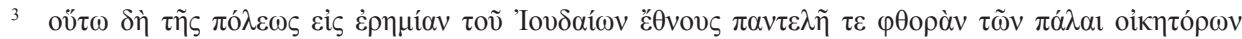

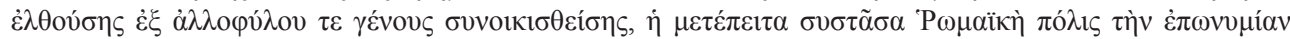

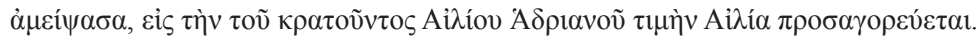

4 Cf. Bowersock 1980, 135; Isaac 1983/1984; Isaac - Oppenheimer 1985, 57; Kindler 2000/2002; Mor 2016, 121-123, 145.

5 On Ariston see Costa 2012; Geiger 2016, 511. Both scholars, like Jacoby, are apparently comfortable with including Eus. HE 4.6.4 as part of Ariston's work.

6 Cf. Avi-Yonah 1954, 30. Pilgrimage, however, may have continued. See Safrai 1980, 386. 
another legion since the end of Trajan's reign. ${ }^{7}$ It then changed its name into Colonia Aelia Capitolina. One may assume that this brief description is a summary either made by Eusebius or found and adapted by him; notice especially that Eusebius calls the place simply Aelia (i.e., not Capitolina), as is his habit elsewhere (HE 2.12.3; 6.20.1; 7.5.1, Theoph. Fr. 12 Gressmann). By misinterpreting his second source, Eusebius erroneously linked the outcome of the Great Jewish Revolt (in 4.6.4) with that of the Bar Kokhba rebellion (in 4.6.3). Yet, even in this melding of sources, Eusebius does not portray the establishment of Aelia as a punitive measure, contrary to subsequent understanding of his passage. ${ }^{8}$ The third and last source Eusebius seems to be using in that chapter is an ongoing Christian list of names of the heads of the church.

If this is true, then nothing prevents us from matching Cassius Dio as epitomized by Xiphilinus and the source used by Eusebius. Both in fact mention the establishment of Aelia Capitolina after the destruction of the Temple, as part of the reconstruction of the city. Any other interpretation of Eusebius may be the result of his own mistake mentioned above, enhanced by a modern misreading of his words.

Moreover, there are some verbal echoes between the two texts: both Cassius Dio

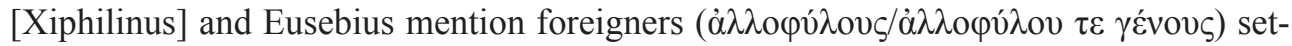
tling (oikı $\sigma \theta \tilde{\eta} v \alpha 1 / \sigma v v o \iota \kappa ı \sigma \theta \varepsilon i \sigma \eta \zeta)$ in Jerusalem. These echoes may have stemmed from Xiphilinus' memory of Eusebius' text, now inserted into Cassius Dio's sequence. But one should not ignore a much simpler solution, that the text read by Eusebius for $H E$ 4.6.4 was in some way related to Cassius Dio 69.12.1-2, as an abridgement. Thus, according to this reading, Xiphilinus found in the ancient historian the very sequence mentioned by Eusebius (Jerusalem being deprived of Jews - foreigners settling there-Aelia), but instead of mentioning the occupation of the city by outsiders as a fact following the city's devastation of its being without Jews, Xiphilinus inserted this detail as a motive for the Jewish rebels who merely waited for Hadrian to depart from the area. Presumably, Xiphilinus did so as to emphasize religious grounds for the revolt, which Cassius Dio did not supply or merely hinted at. ${ }^{9}$

Another source which perhaps is worth mentioning here is that of Epiphanius, the fourth century AD Bishop of Salamis, in his On Weights and Measures (14), who seems to follow the same framework, in his description apropos of Hadrian's journey to the east $(128-132 \mathrm{AD})^{10}$ and the biblical translator Aquila's arrival in Jerusalem. The relevant passages are the following:

This Hadrian [...] set forth to the land of the Egyptians. And when he advanced from Rome to these [cities] one after the other, it was necessary for him to explore those cities, because he was a curious person. Accordingly, he passed through the city of Antioch, went beyond Coele [Syria] and Phoenicia, and arrived in Palestine, which is also called Judaea, 47 years after the devastation of Jerusalem. And he went up to Jerusalem, the celebrated and famous city, which Titus son of Ves-

7 In fact, after the destruction of Jerusalem only a small detachment encamped in the Upper City. See Geva 1984, 246.

8 Cf. Ecker - Cotton 2018/2019, 60 and Cotton 2018/2019, 66.

9 In the same manner Xiphilinus' claim that on the site of the temple of the God Hadrian raised a new temple to Jupiter is his own interpretation. See Erlich 2003. This is contrary to what is known. See Eliav 1997.

10 On the visit, see von Rohden 1893, 509-513; Halfman 1986, 192-194, 203-208; Syme 1988; Birley $1997,215-278$. 
pasian destroyed in the second year of his reign. And he saw the entire city levelled to the ground

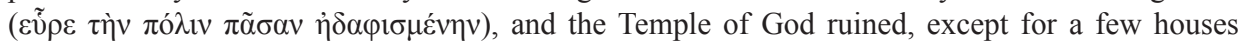
and for the small church of God [...] At all events, Hadrian intended to build the city, and not the temple. And after he took Aquila [...] he appointed him to that place in Jerusalem as an overseer of the building works of the city, having given to the city, which was being built, his own name and the designation of the imperial name. For as he was called Aelius Hadrianus, so he called the city Aelia (trans. R. Baker).

There are many signs that Epiphanius is joining several sources here. ${ }^{11}$ As clearly shown by Baker (2012, 159-163), Epiphanius combines some fairly accurate information concerning the sequence of Hadrian's travel with inaccurate chronology for the destruction of Jerusalem (81 AD) and the date of Hadrian's arrival (adventus) in Judaea (128/129 instead of the actual 130 AD), along with a digression (not brought above) describing Jerusalem in his own period at the time of Constantine, and another digression on Aquila. Apart from the digressions, Epiphanius follows the same structure noted above, creatively embellished by him: the destruction of Jerusalem (as seen by Hadrian), and at the end the founding of Aelia. In between, in the part that mentioned the occupation of Jerusalem by foreigners, the Bishop elected to insert the presence of the Christians in Jerusalem. Epiphanius may have used a source close to the structure of Cassius Dio's text.

The order of events originally found in Cassius Dio's book placed the establishment of a city in Jerusalem before the detailed recounting of the revolt. But this point should not be pressed too much, as we cannot be sure whether his sequence was chronological. In fact, we have reasons to believe that it was not. Dio's account is known to be not strictly annalistic or even chronological, but rather occasionally thematic. ${ }^{12}$ In the section on Hadrian in particular ${ }^{13}$ Dio recounts the emperor's visit to Egypt, claiming that he "passed through Judaea" (69.11.1), continues with Antinous' death and the honours given to him (69.11.2-4), and then returns to Judaea. Dio proceeds from the Jewish revolt and its suppression (69.12-14) to the invasion of the Alani (69.15) and back to the emperor's visit to Athens in 131/132 (69.16.1-2). ${ }^{14}$ Xiphilnus' epitome probably preserves Dio's original structure, ${ }^{15}$ as well as his predecessor's concern with building undertakings. ${ }^{16}$ This is indeed one of the unifying themes of the Hadrianic portion, in that the sections $69.10,11,12,16$ each begins with a brief introduction to the section

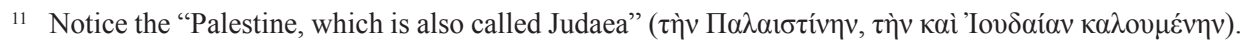

12 See Millar 1964, 40: "The [annalistic] principle [...] was by no means rigidly adhered to [...] in the imperial period also each reign begins and ends with a collection of material taken out of its chronological setting and designed to illustrate the character and manner of government of the Emperor concerned [...] Even in the supposedly chronological sections, however, he does not keep strictly to the annalistic structure." See Swan (2004, 103): “Dio is writing thematically." See Bellemore 2003, 273; Lange - Madsen 2016, 2: “[Dio's] work does not present itself as exclusively annalistic in nature, but also as a series of imperial biographies, beginning with the dynasts of the Republic." Cf. Kemezis 2014, 101.

13 See Millar 1964, 67: "It is clear, even from the fragmentary text we have, that the annalistic section is not as annalistic as it might be, for here too the material tends to be grouped round leading characteristics of the main figure and the chronological sequence, if never entirely lost, is often vague in the extreme." Cf. Millar 1964, 71.

14 See Millar 1964, 70: "another indication of how far he had abandoned annalistic methods."

15 Cf. Bellemore 2003, 269.

16 See Gowing 2016. 
with a building project of the emperor and then digresses to elaborate on its circumstances. ${ }^{17}$ The Jewish revolt is such a digression. The sequence of the revolt appears to follow the same pattern of the paragraph on Antinous, in which the mention of the chronologically later event like the establishment of the city in his honour (69.11.2) precedes an account of earlier occurrences (69.11.2-4). The opening of the section, dealing with the establishment of Aelia Capitolina, and giving an overarching outline of the history of the building program, was thus seemingly detached from the main body of the description. It was perhaps so detached that it alone was summarized by Eusebius' source for $H E$ 4.6.4.

If this is true, Dio did not believe the establishment of Aelia Capitolina chronologically took place before the Bar Kokhba revolt, and Xiphilinus was led astray by the thematic arrangement of his source. ${ }^{18}$ Ostensibly, the picture emerging here might be validated by the sequence found in the Mishnah, Ta'anit Tractate 4:6 relating to events that occurred on the $9^{\text {th }}$ of Av:

[On this day] it was decreed that our fathers would not enter the Land of Israel, ${ }^{19}$ the Temple was destroyed the first and second time, Betar was captured, the city [of Jerusalem] was ploughed over.

The reference to ploughing alludes to the archaic Roman (and Etruscan) ceremony of ploughing the furrow (sulcus primigenius) around a new city with a pair of oxen demarcating its religious and sacred limits (the pomerium; see Dion. Hal. AR 1.88; Varro, Ling. Lat. 5.143). Betar was the last stronghold of Bar Kokhba's revolt, and hence the ploughing of Jerusalem as a part of the foundation of the new city was allegedly done after the suppression of this revolt. ${ }^{20}$ Yet, as Hadrian is often conflated with Vespasian or Titus in Jewish sources, ${ }^{21}$ so are the two revolts. What the sequence may imply is that for the redactor, who apparently wishes to follow a chronological scheme, the Roman colony in Jerusalem was established after the suppression of a Jewish rebellion. The memory of the Great Revolt was intermingled with that of the Bar Kokhba revolt. We should accordingly not be surprised that in to the Bab. Talmud (Ta'anit 29a) the ploughing took place while Rabban Gamliel was still alive, that is, shortly after the destruction of the Temple. Therefore, this passage would not help us date the founding of the colony more accurately.

There is in fact no strong evidence to suggest that Aelia Capitolina was founded in $130 \mathrm{AD}$, on the occasion of Hadrian's visit to Judaea, as part of his travel to the east, despite constant assertions in research that there is. ${ }^{22}$ The archaeological finds are not

17 See Millar 1964, 40: "the introduction is often marked off explicitly from the chronological section."

18 Perhaps relevant here is the curious use of temporal sequence in Epiphanius' text (above). Why would

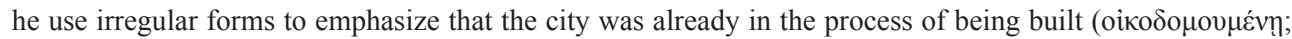

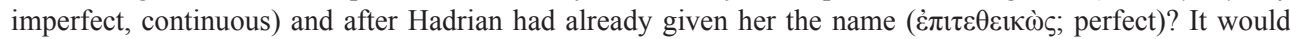
appear that the reason was to settle a crux in his source, which placed an event which was chronologically later, like the naming of the city, as thematically first. If this reading is correct, it would fit the text of Dio as abbreviated by Xiphilinus.

19 See Numbers 14:1-25.

20 Cf. Smallwood 1981, 459.

21 Cf. Schäfer 1981a, 81, 90; Mor 2016, 250-251, 284. This is true even in passages which appear to refer specifically to Hadrian; cf. Exodus Rabba 51:5, Deuteronomy Rabba 3:13, Tanhumah Genesis 10:7.

22 E.g., Birley 1997, 232-233; Magness 2011, 313. See, however, Oppenheimer - Isaac 1987, 416. 
so clear-cut. Below the paving stones of the eastern colonnaded street (the cardo) in Jerusalem were discovered a coin and fragments of pottery vessels dated to the reign of Hadrian. ${ }^{23}$ An ancient quarry located along the route of the cardo and sealed under the pavement, and which was presumably filled during the preparation works preceding the paving of the street, contains many finds. ${ }^{24}$ Although Weksler-Bdolah $(2014,56)$ argues that these finds "allow a secure dating of the deposit to the first third of the second century CE (c. 100-135 CE)," in fact, the only ones which can be attributed to this period with certainty are two seeds from which she asserts were dated, by means of $\mathrm{C} 14$, to the years 5-125 AD and 20-135 AD respectively. This means that the road was paved during Hadrian's rule, but it would appear that the inference cannot be more precise than that. Therefore, the conclusion that the preparation works preceding the paving of the street "started early in Hadrian's reign, probably around the $120 \mathrm{~s}$ " 25 does not necessarily follow from the findings. But let us accept for the moment that it does. When was the final phase of the construction of the city?

The Aelia Capitolina bronze coins, which publicize the founding of the colony, with the well-known reverse of Hadrian ploughing the pomerium with oxen, the legionary standard (vexillum of the Tenth Legion) and the legend COL AEL KAPIT COND (Colonia Aelia Capitolina Condita), are notoriously difficult of dating, as they contain no datable titles or signs. On the one hand, Hadrian's title is given on the obverse of some types as IMP CAES TRAIANO HADRIANO (e.g., Sear 2000, no. 1249), reverting back to the coins of his early reign, which emphasized his adoption by Trajan. ${ }^{26}$ On the other hand, the title includes the legend P P (PATER PATRIAE), which the emperor used from 128 AD. ${ }^{27}$ There are other such hybrid Hadrianic legends in local coinage, as one from Pella (Sear 2000, no. 1121) or another from Berytus, Phoenicia (Sear 2000, no. 1242). Coins from Bithynia (Mattingly - Sydenham 1926, nos. 459-462) and Provincia Asia (Mattingly - Sydenham 1926, nos. 463-464) follow the same pattern of the Aelia Capitolina coins (IMP CAES TRA HADRIANO AVG P P). As Mattingly and Sydenham (1926, 319), claim "[these] have no counterpart in Rome." They assign these coins, therefore, "tentatively" to Hadrian's second visit, in $130 \mathrm{AD}$. But this is by no means certain. The only secure way to set a precise date to the Aelia Capitolina coins might be to find any such specimen with other datable coins in a hoard, the assumption being that such a hoard friezes a fixed, datable moment in time. ${ }^{28}$

Hoards of coins containing both Aelia Capitolina and Bar Kokhba coins, which are relatively easier to date, appeared since 1967, allegedly coming from illegal excavations in the northern Judean desert. Yet, since these coins were not found in a controlled excavation, there was no assurance that they indeed came from the same hoard and thus supposedly minted before the revolt began. It is one controlled excavation, however, in elJai Cave, in Nahal Mikhmash (Wadi Suweinit), northeast of Jerusalem, conducted by

23 See Weksler-Bdolah 2014, 52, 54.

24 Weksler-Bdolah 2014, 54: "Roman dump."

25 Cf. Weksler-Bdolah 2011, xix.

26 Mattingly 1925, 209.

27 Cf. Mattingly 1925, 209; Mattingly - Sydenham 1926, 315; Eck 1982, 218, 220-221.

28 Cf. Buttrey 1999. 
Eshel and Zissu in 1997 and 1998, that may give us a more precise date. The excavations yielded together 16 coins datable to the period from Claudius to Hadrian, including ones belonging to the Bar Kokhba revolt. It is supposed that Jewish rebels fled to the cave during or after the revolt, and that they were in possession of regular Roman coins alongside the ones of the rebels. Assuming that these finding are not contaminated by later periods, ${ }^{29}$ the juxtaposition of several coins in that hoard makes the dating somewhat easier. It is the combination of four Bar Kokhba coins, three from the second year of the revolt (133/134 AD) and one from the undated series minted in the third or fourth years of the revolt (134/135 or 135/136), with the legends "For the Liberation of Jerusalem" ) together with a Gaza coin minted in the double date year five (after the year of Hadrian's visit, 129/130 AD) and year 194 (of the Gaza Era, since 61 BC) - that is, year 133/134 AD — that is most helpful.

Eshel and Zissu (2000/2002, 173) claim that the Aelia Capitolina coin was thus minted before 135 AD. But since the undated Jerusalem Bar Kokhba coin was struck in both the third and fourth years of the revolt, the year 135/136 AD could be taken as the chronological limit for the hoard. This fact again does not inevitably entail that the colony was founded in $130 \mathrm{AD} .{ }^{31}$ Eshel and Zissu suppose that the city mint only began operating before $135 \mathrm{AD}$, that is, during the revolt. ${ }^{32}$ Yet, it may be that the colony itself was founded as Aelia Capitolina not long before that date, and that in effect this foundation occurred during the revolt. ${ }^{33}$ Moreover, if we allow the chronological limit to be pushed towards the fourth year of the revolt and towards $136 \mathrm{AD}$, this places the foundation of the colony almost near the end of the war, and marks it as one of the measures taken during the last stages of its suppression. ${ }^{34}$

If this is true, then either the decision to establish a Roman colony in Jerusalem was taken after the revolt was over (or near its end) or the decision was made earlier (presumably c. $130 \mathrm{AD}$ ), but the name and character of the new colony were decided near its final suppression.

A combination of evidence from various sources may corroborate the latter complex and more nuanced picture. A Greek inscription from Hierapolis (Asia Minor), contains a letter from Hadrian dated to $130 \mathrm{AD}$, which confers a privilege to that city and is signed

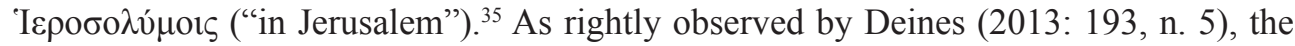

29 See Eshel 1997, 48: "[w]hen I led a group of students here in 1997, we found evidence of intensive illegal excavations"; Eshel - Zissu 2000/2002, 169: "intensive looting of the cave in recent years."

${ }^{30}$ For the series, see Kindler 1974, 64-65, 68-69. See Meshorer 1967, no. 214; Kindler 1974, nos. 141-142. Cf. Meshorer 1967, 186-189, 194-195, 199-215; Kindler 1974, nos. 110-140; Mildenberg 1984, 306, no. 33 .

31 Pace Kindler 2000/2002, 177. See Zlotnik 2008, 142 note 10. Cf. the argument made by Herr 1978, 9, note 42, on the hoard presented by Meshorer in 1967.

32 Eshel - Zissu 2000/2002, 175: “it took time to complete the building and organization of the city's mint."

33 As Meshorer 1989, 21, claims, "as soon as the city was founded [...] it began to mint coins." His date for this is $130 / 131$, but it could have been later.

34 Zlotnik 2008 appears to suggest that when the Romans reconquered Jerusalem from the rebels, they reestablished it. This could be true without resorting to the assumption that the city had to be taken again by Romans.

35 See Ritti 2004, 336 (line 13), 337-339. 
publication of the letter, which makes it explicitly clear that Hadrian still employed in 130 the traditional name of the city, "may change the discussion" concerning the date of the establishment of Aelia Capitolina. It means that during Hadrian's visit, the name has not yet changed, ${ }^{36}$ and that the foundation ceremony probably did not take place in his presence. ${ }^{37}$ One should remember that Hadrian's stay in Jerusalem (and Judaea) was relatively short in any case (between March and July/Aufust 130 AD). ${ }^{38}$

We can adduce the testimony of Pausanias (8.16.5), for what its worth, who mentions the tomb of Helena (most probably the daughter of Izates, king of Adiabene, and wife of Monobaz I, her brother, and Abgarus V of Edessa, who herself converted to Ju-

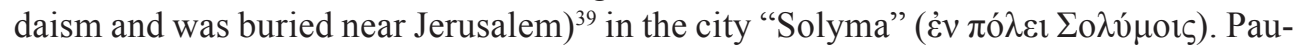
sanias employs a name for Jerusalem which was common among Flavian authors, ${ }^{40}$ as essentially rebranding the devestated city with a play on the old name (with an archaic allusion that goes back to the Odyssey 5.283). ${ }^{41}$ Pausanias also notes that the city was

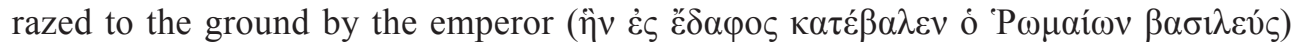
- presumably in the Great Revolt - and he does not refer to any Roman colony established in its place. Pausanias himself travelled to the "land of the Hebrews," as he claims (Jaffa: 4.35.9, Sea of Galilee and the Dead Sea: 5.7.4-5; cf. 6.24.8, 9.19.8). We do not know the date of his visit (or visits?). It could have been before or during Hadrian's visit to the east, but it could have been later, after the Bar Kokhba revolt. Pausanias' descriptions do not seem to betray any knowledge of the revolt. The refer-

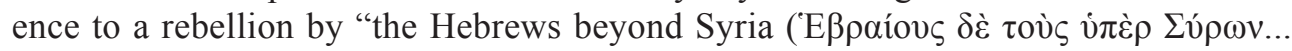

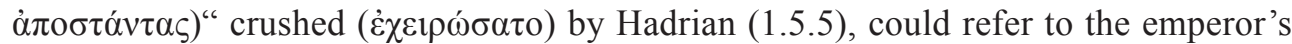
involvement in reducing a local unrest in 117 AD (SHA Vit. Hadr. 5.2, 8), effected by the Diaspora revolt, while he was still in Syria ${ }^{42}$ (cf. SHA Vit. Hadr. 4.6; Cassius Dio 68.33.1; 69.2.1), ${ }^{43}$ and not to the Bar Kokhba revolt. ${ }^{44}$ Why else would Pausanias use this obscure phrase to describe the Jews of Judaea? ${ }^{45}$ Given that his books were composed much later than the occurrences, he was surely not unaware of the revolt by then. If Pausanias' descriptions are based on notes he took at the time of his sojourn in the area, and while composing, he intentionally disregarded all that had happened after his travel, and if this visit coincided with Hadrian's own (if Pausanias was born c.

36 Correctly noticed by Mor 2016, 128, note 514. A point lost on Cotton 2018/2019, 66 .

37 The description of Birley 1997, 233, to the effect that "[o]ne may suppose that a founding ceremony took place with Hadrian's participation" is purely conjectural and fanciful and does seem to go against the facts. Hadrian merely passed through Judaea on his way to Egypt, as Dio writes, and his stay in Judaea was perhaps so brief that no wonder the SHA Vit. Hadr. fails to even mention it.

38 See Halfman 1986, 194, 207; Birley 1997, 233-238; Baker 2012, 161.

39 Cf. Jos. AJ 20.17-51, 94. Cf. Eus. HE 2.12.3.

40 Cf. Val. Fl. Argon. 1.13; Mart. 7.55.7, 11.94; Statius Silv. 5.2.138 and Jos. BJ 6.438; AJ 1.180, CA 1.173-174. See Labow 2005, 188, note 82.

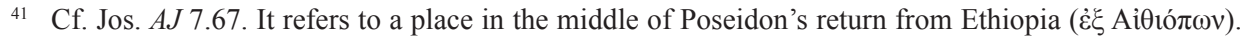
A people called Solymoi is known in Lykia or Pisidia (Il. 6.184, 204; cf. Hdt. 1.173.2; Strabo 1.2.28; 13.4.16).

See von Gutschmid 1893, 572.

42 Cf. Birley 1997, 75-76; Dąbrowa 1998, 89-90.

43 Cf. Pucci Ben Zeev 2005, 232-233 and in general 219-257.

44 Pace Stern 1980, 192 and Geiger 2016, 505.

45 And the phrase appears to be deliberately anachronistic, as Judaea was now part of the same province Syria-Palaestina. 
110 AD $)^{46}$ then Pausanias' text is also significant for asserting that in c. 130 AD Aelia Capitolina was not yet established. ${ }^{47}$

There is one tradition found in Jewish sources that is usually brushed aside, but perhaps needs some attention. This is the tradition found in the fourth to sixth centuries AD text Midrash Genesis Rabba (64:29), of an unfulfilled plan to rebuild the Temple, that was abandoned because of machinations from the Samaritans. The relevant sections are these:

In the days of Rabbi Joshua ben Hananiah the [Roman] State ordered the Temple to be rebuilt. Pappus and Lulianus set tables from Acco as far as Antioch and provided those who came up from the Exile [i.e. Babylon] with all their needs. Thereupon Samaritans (Kuttim) went and warned [the Emperor]: 'Be it known now unto the king, that, if this rebellious city be builded and the walls finished, they will not pay tribute (mindah), impost (belo) or toll (halakh)' ... 'Yet what can I do,' said he, 'seeing that I have already given the order?' 'Send a command to them that they must change its site or add five cubits thereto or lessen it by five cubits, and then they will withdraw from it of their own accord.' Now the Community [of Israel] was assembled in the plain of Beth Rimmon; when the [royal] dispatches arrived, they burst out weeping, and wanted to revolt against the [Roman] power... ${ }^{48}$

Most scholars reject any historical value to this passage. ${ }^{49}$ Baker (2012: 163, n. 42) does not even see it as relevant to the rebuilding of Jerusalem by Hadrian. ${ }^{50}$ Yet, if we remove several elements, such as a clear allusion to Ezra 12:4 and the role of the local population there in halting the reconstruction of the Second Temple, the tradition may preserve a vague memory of historical reality; in particular, a memory of two plans in the reconstruction of Jerusalem, one replacing another. The references in the Midrash to a possible Jewish rebellion should the emperor proceed with his original plan may be faint echo of the Bar Kokhba revolt, and how this alteration of plans was its result. One should notice that in the story, there is no hint of an actual revolt after the plans have changed. ${ }^{51}$

Somehow related to the approach in this Midrash, is the testimony of Epiphanius we saw above. He emphatically states that "Hadrian intended to build the city, and not the Temple"

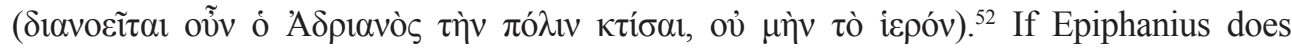
not insinuate the recent effort of the emperor Julian (363 AD) to rebuild the Temple, ${ }^{53}$ he

46 Cf. Bowie 2001, 23, followed by Geiger 2016, 505. See, however, Habicht 1985, 9-12: 115 AD. See also Akujärvi 2005, 87; Pretzler 2007, 23.

47 Cf. Geiger 2016, 506: "The reference to Jerusalem in a rather antiquarian way most probably reflects the time of his stay there, perhaps somewhat predating Hadrian's visit to the country or coinciding with it and probably before naming the city Aelia Capitolina."

48 Trans. from Hebrew and Aramaic: H. Freedman. Found in Mor 2012, 162.

49 For example, Mor 1991, 171-173; Mor 2016, 118. The few exceptions are: Schürer 1973, 93-94, 535-536; Herr 1978, 4-5; Bazzana 2010; Capponi 2010.

50 The mention, however, of Lulianos and Paphos (i.e., Julianus and Pappus), the two second centrury AD Jewish brothers, martyrs of Laodicea (Megilat Ta 'anit 12, Bab. Talmud Ta 'anit 18b) makes the chronological link clear.

51 See Mor 2016, 118, who claims the Midrash contains no trace of a storm that was aroused when it was allegedly obvious that the emperor's plan had no room for the Temple in the reconstructed city.

52 As Baker 2012, 162 succinctly puts it, "we read nothing about ... what was built in the city, but rather what was not built."

53 See Baker 2012, 163. For the efforts see Amm. Marc. 23.1.2-3; Socrates Scholasticus HE 3.20; Sozomen 5.22; cf. Julian Epistle 51. Cf. Jerome Comm. Daniel 11:34. See Levenson 2004. 
seems to echo the tradition of Hadrian's two designs for the reconstruction of Jerusalem, one adopted after another was discarded.

What shall we make of the local Roman provincial coins restruck by Bar Kokhba to have the legend "for the freedom of Jerusalem" or have an architectural building on the obverse, ${ }^{54}$ which is taken plausibly to represent the Temple? ${ }^{55}$ What to make of the musical instruments depicted on the coins' reverse (trumpet, harp) ${ }^{56}$ or the Lulav (palm frond), the Etrog (yellow citron), or the willow branch associated with Temple worship or brought to the Temple in the Feast of Tabernacles (Sukkot) $?^{57}$ A proper understanding of the legends on the rebels' coins would seem to be that they indeed occupied and "freed" Jerusalem, if only for a short while. ${ }^{58}$ Some scholars have assumed that the coins imply that Jerusalem was taken by Bar Kokhba warriors and reconquered by Hadrian. ${ }^{59}$ Ostensibly, this also appears to be the right interpretation of Sanhedrin Tractate $97 \mathrm{~b},{ }^{60}$ according to which the first kingship (of the Hasmoneans) was 70 years, the second (of Herod) 52 years and the third, of Bar Koziba (=Bar Kokhba) two years and a half. Furthermore, some believe that the images and designs depicted on the rebels' coins, linked with Temple celebrations, imply that actual steps were being taken by Bar Kokhba's men to renew worship and cultic sacrifice in Jerusalem. ${ }^{61}$

Yet, there are cogent arguments (recently all assembled in Mor 2016, 249-288) that the rebels never really held Jerusalem. ${ }^{62}$ These are not of the kind arguing that the number of Bar Kokhba coins found in Jerusalem (five in all) ${ }^{63}$ is insignificant as compared to the alleged centrality of the place if the rebels had actually taken it. ${ }^{64}$ That is essentially an argument out of silence, and as Zlotnik (2008: 140-5) has rightly shown, the number of Aelia Capitolina coins found so far within the area of Jerusalem is the same. The more devastating arguments are rather that it is hard to imagine the guerrilla warriors taking a city (without any experience of siege warfare) and spending energy in occupying and protecting it. ${ }^{65}$

In that case, the legend "Jerusalem" may be construed as a mere war slogan (i.e., "for the freedom of Jerusalem" means "let us fight to free Jerusalem"). ${ }^{66}$ This war cry

54 See Meshorer 1967, 165, 178, 181; Kindler 1974, nos. 81, 92, 97-98, 116-119.

55 Reifenberg 1965, 56.

56 See Sirach 50:14-20; Middot Tractate, 2:6.

57 Cf. Meshorer 1967, nos. 164, 172, 177, 182-183, 186-187, 194, 199-205, 207-209; Kindler 1974, nos. 88, 95, 97, 99-103, 111, 115-119, 121-133. Cf. Leviticus 23:40, Jos. AJ 3.244-247, and cf. 4.203-205. Cf. Plut. QC 4.6.671-672. See Sukka Tractate 5:1-4. On the connections of the Sukkot with the restoration of the Temple see Romanoff 1971, 59-62 and Ezra 3: 1-5; 2 Macc 1:18; 10:5-8. See Lapin 1993, $130-134$.

58 See Reifenberg 1965, 36; Kanael 1971, 39-46; Kindler 1974, nos. 69, 175-176.

59 Alon 1989, 615; Yadin 1971, 18; Schürer 1973, 545; Smallwood 1981, 444; Oppenheimer 1982, 60.

60 Relating to the question of when the Messiah will come, in an interpretion of Habakuk 2:3: "For the vision is yet for an appointed time; But at the end it will speak, and it will not lie. Though it tarries, wait for it; Because it will surely come, It will not tarry" (NKJV).

61 See Luria 1972, 71-72, 79; Ginzburg 1972.

62 See Mildenberg 1977; Bowersock 1980, 136.

63 Cf. Barag 1980 For the mints cf. Barag 2002. For the mints cf. Barag 2002.

64 See Applebaum 1976, 27, 83, note 211; Mildenberg 1980, 320; Barag 1980, 31, 33; Schäfer 1981a, 87-88; Ariel 1982, 293; Mor 2016, 260.

65 See Applebaum 1984, 41; Mor 2016, 287-288.

66 See Applebaum 1984, 41; Mildenberg 1949, 90-94; Mildenberg 1997, 1998, 212-234 [225, 228]; Eck 1999, 76; Zissu - Eshel 2001, 25; Mor 2016, 280. Cf. Romanoff 1971, 38. 
was apparently thought by the rebels to be effective in enlisting support from the Jewish population, even non-participants in the actual revolt. It would seem to imply that of the known responses to the calamity of the destruction of the Temple, the one anticipating the rebuilding of the Temple in particular appeared to gain currency among the Jews at the time. ${ }^{67}$ This response appeared alongside three other attitudes, namely (1) one which required special practices for remembrance of the Temple and Jerusalem, instituting a day of fast on the $9^{\text {th }}$ day of the month of $\mathrm{Av},{ }^{68}$ in which all prohibitions applicable to a private mourner were on this day effective for the entire nation, ${ }^{69}$ (2) an attitude which enacted new regulations in memory of the destruction as a substitute for observances which were practiced when the Temple was extant, ${ }^{70}$ and (3) a response which seems to tone down the tragedy resulting from the destruction, in opposing the spread of despairwhich came from the halting of ordinary Temple activities, ${ }^{71}$ and in decreeing that the remembrance be displayed in partial acts of grief. ${ }^{72}$

Evidence for the religious - messianic approach can be seen in several traditions (some of them admittedly developed later), such as the one associating the day of the fast ( $9^{\text {th }}$ of Av) with the birthday of the Messiah. ${ }^{73}$ It is also noticeable in several enactments, which promise a great strictness of the law in present time, as if the new Temple is already standing, the reason being that when the Temple is rebuilt, no leniency is be admitted in the case of the regulations. For instance, the sages abolished the tithing of cattle (Ma'asar B'hemah) for fear that an unblemished animal be put to work or slaughtered when it might be needed for sacrifices (Talmud, Bechorot 53b) while "the Temple be speedily rebuilt." Similarly, priests would not drink wine, for the Temple will be reconstructed soon (Talmud, Ta'anit 17a).

67 Indeed, there are traditions that the sage Rabbi Akiva supported the rebellion because of his belief in the imminent deliverance. See Jer. Talmud, Ta anit 4:6, Pesachim Tractate 10:6. See Shachar 2003.

68 The day actually commemorated five calamities (Ta'anit Tractate 4:6, see above).

69 Eating or drinking, washing, application of oils, the wearing of leather shoes, and conjugal relations (ib.).

70 For instance, the Musaf prayer was introduced instead of the additional sacrifices offered in the Temple on certain dates (Bab. Talmud, Berachot 26b). On Jewish Prayer as replacing sacrifice, see Berachot Tractate 5:3. See the reaction of several of R. Yochanan b. Zakkai's pupils: Avot Tractate 2:8. Cf. Fleischer 1990. Similarly, the lectern is placed in the centre of the synagogue during the Feast of Tabernacles (Sukkot) and a circuit is made around it, as was done around the altar in the Temple (Sukka Tractate 4:5 and Bab. Talmud, Sukka 43b). The eating of bitter herbs on the first night of Passover together with the Mazah is in memory of the Temple (Talmud, Pesachim 115a: "in memory of what Hillel used to eat in the time of the Temple").

${ }^{71}$ The locus classicus for this attitude is in the saying of Rabban Simeon ben Gamliel (Tosefta Sotah 15:10): "From the day that the Temple was destroyed, it would have been logical that we not eat meat and not drink wine. However, the court may not decree upon the congregation things to which they are unable to follow." There is also evidence of rabbinic attempts to minimize the 9th of Av as a day of mourning, at least on Shabbat: Jer. Talmud Ta'anit 4:9, 69c. Cf. Jer. Talmud, Yabamot 6:6 7d; Megillah 1:6, 70c; Bab. Talmud Megillah 5a-b. In an important assertion, the sages claimed that "to mourn excessively is not possible" (Rabbi Yehoshua, Tosefta Sotah 15:12).

72 Tosefta Sotah 15:12-13: "A man shall plaster his home with plaster and leave over a small bit as a remembrance of Jerusalem; A man may prepare all the needs of a meal, and leave off a little bit as a remembrance of Jerusalem. The sages continue: whoever mourns for [Jerusalem] in this world will rejoice with her in the world to come" (an interpretation of Isaiah 66:10).

73 Ester Rabba, Petichtah ("beginning") 11; Midrash Zuta, Lamentations 1. 
Hence, the Temple-related objects and Jerusalem-related legends on the rebels' coins would indicate not actual renewal of the worship in Jerusalem ${ }^{74}$ but only belief in the coming religious and national redemption, in which the Temple soon would be rebuilt. Should we therefore deny any relevance of Bar Kokhba's War to the actual Jerusalem, contrary to the persistent traditions hinting at his occupation of the city? It is proposed here that we should not.

The point worth contemplating is that the rebels, by their means of guerrilla warfare, may have succeeded in halting the Roman reconstruction works in Jerusalem, certainly in the first and perhaps also in the second year of the revolt (134 AD), when the Romans began to effectively reduce the insurgence (Cassius Dio 69.13.1-3: Sextus Julius Severus). ${ }^{75}$ This success may be at the core of these oral traditions associating Bar Kokhba with Jerusalem. It may account for the surge in the religious hopes that the Temple will soon be rebuild and for Bar Kokhba's ability to procure some support from the Jewish population in Judaea. This success may also explain a certain impression emerging from our sources of a break in the implementation of Hadrian's plans to reconstruct the city and of some disruption to the imperial original plans. It would also clarify the description of two literary sources, which might be taken to imply a reoccupation of Jerusalem by Hadrian during the revolt. According to Appian's Syrian Wars (Syr. 50.252):

The Jewish nation still resisted, and Pompey conquered them, sent their king, Aristobulus, to Rome, and destroyed their greatest, and to them holiest, city, Jerusalem, as Ptolemy, the first king of Egypt, had formerly done. It was afterward rebuilt and Vespasian destroyed it again, and Hadrian did the same in my time (trans. H. White, LCL). ${ }^{76}$

Appian clearly misinterprets his information on Jewish history and Jerusalem. ${ }^{77} \mathrm{He}$ probably misunderstands how in the Jewish mind-set, the building of Aelia Capitolina equals a destruction of the city. ${ }^{78}$ Appian's mention of Vespasian appears to make it likely by analogy that the foundation of the colony came after the revolt began. But the interesting point in this sequence is that between Vespasian's action and the one made by Hadrian, the city was "rebuilt" (as it was before Vespasian). It was apparently rebuilt and then destroyed (by the founding of Aelia Capitolina). The only possible rebuilding of Jerusalem after Vespasian is that of Hadrian, and therefore the only plausible explanation to this garbled picture would be to assume that the colony was founded after the revolt began, and that there was a hiatus between the "building" (first phase) and the foundation of the colony (which is tantamount to destruction). This hiatus must be interpreted as the temporary success of Bar Kokhba to halt the reconstruction.

74 See Mor 2016, 273.

75 See Eck 1999, 78-79, 82. Cf. Dąbrowa 1998, 94-96; Mor 2016, 351-353.

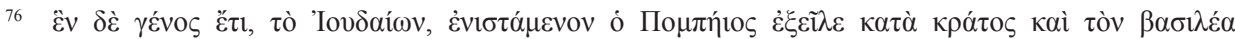

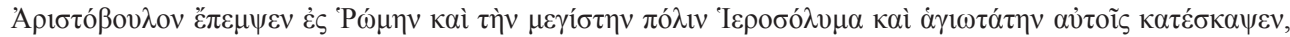

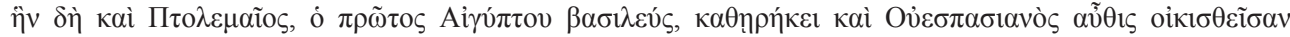

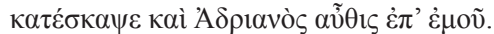

77 Cf. Mor 2016, 268.

78 As noted by Schäfer 1990, 282. Cf. Stern 1980, 179-180. Cf. Jer. Talmud Ta'anit 69c, in which Rufus (Quintus Tineius Rufus) is said to have ploughed the Temple (as if the ploughing a new city is destroying the Temple) — while the local authority is equated with the chief one (Hadrian). Cf. Bab. Talmud, Ta'anit 29a. 
It would appear that an equally vague picture by Eusebius elsewhere (Demons. Evang. 6.18.9-10) is the result of a similar attempt to come to grips with what actually happened between the destruction at the time of Titus/Vespasian and Hadrian:

From the time of Pontius Pilate to the sieges under Nero, Titus and Vespasian [the Jews] were never free from all kinds of successive calamities, as you may gather from the history of Flavius Josephus. It is probable that "half the city" at that time perished in the siege, as the prophecy says. And not long after, in the reign of Hadrian, there was another Jewish revolution, and the remaining half of the city was again besieged and driven out, so that from that day to this the whole place has not been trodden by them (trans. W.J. Ferrar). ${ }^{79}$

Eusebius' allusion to Zechariah 14:2 conveniently allows him to link the calamities of the two revolts and present them with a spatial metaphor. Eusebius is led by his own spatial imagery to imply that Jews continued to stay in Jerusalem (allegedly, in the half not devastated) till the second revolt; but this is merely rhetorical. He certainly does not mean that they occupied Jerusalem momentarily and were besieged. ${ }^{80}$ Yet, if there is any historical merit to this imagery it is that Jerusalem was partially devastated and partially built when Hadrian was suppressing the rebels. That is to say, the revolt broke out when Hadrian's reconstruction was not yet complete and his power to finish the project of rebuilding was temporarily curbed.

So to conclude our note: Aelia Capitolina, according to the view presented here, was founded during the last stage of the revolt and parallel to the continuous effort to seize the remaining rebels in their hideouts. It is another question whether this situation indicates that the rebels were no longer perceived as a threat, although they were not completely crushed, and whether the clash at Betar was indeed dramatic. ${ }^{81}$ The coins certainly testify that the mint announcing the foundation of the city began operating during the revolt and before it was completely eradicated. There was apparently some delay in the establishment of the colony, presumably because of the revolt. If this is true, this fact would explain why it was important to found the colony during that stage. It would seem that just as the legends on the Bar Kokhba coins were an ideological slogan that unified the rebels, and encouraged them during the year (or two) when reconstruction work in Jerusalem ceased, the completion of the foundation of the colony (if not the issue of coins celebrating it) eroded the morale among the Jewish warriors. ${ }^{82}$ It was not a punitive

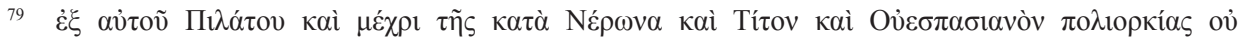

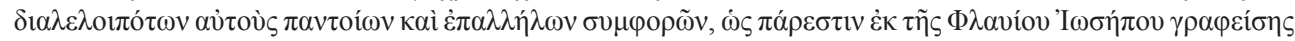

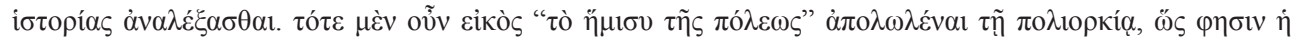

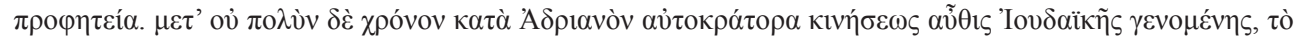

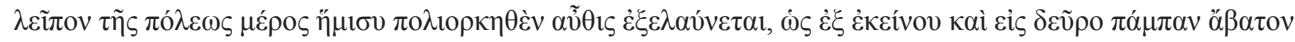

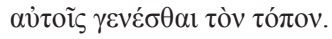

${ }^{80}$ A note should be made on the siege imagery here. This could be Eusebius' misinterpretation of his source which may have described how the Romans were able to crush the revolt by intercepting small groups of warriors, depriving them of food and shutting them off (close to Cassius Dio 69.13.2-3); Cf. Eus. Demons. Evang. 2.3.86; HE 5.12.1. In other words, his source presumably did not mention a siege on the Jews within the city, but rather curbing their movement from without, in their respective hideouts. Cf. Schäfer 1981b, 95. See, however, Lifshitz 1977, 482.

${ }_{81}$ See Eck 1999, 88: "serious fighting against Bar Kokhba did not end in 135, but only in 136." Cf. Mor 2016, 326, 343.

82 Similar actions to demoralize the rebels were perhaps those relating to the so-called ban on circumcision (SHA Vit. Hadr. 14.2), which could be seen a severe implementation of Hadrian's rescript (Digesta 
act but an action that had pragmatic advantages. Thus, the real order of the coins was the opposite of that suggested by Eshel and Zissu (2000-2002: 175): first, the Bar Kokhba coins depicting Jerusalem and then the Aelia Capitolina foundation ones.

BIBLIOGRAPHY

Akujärvi, J. (2005), Researcher, Traveller, Narrator: Studies in Pausanias'Periegesis, Stockholm.

Alon, G. (1989), The Jews in Their Land in the Talmudic Age, 70-640 CE, trans. and ed. G. Levi, Cambridge, MA.

Applebaum, S. (1976), Prolegomena to the Study of the Second Jewish Revolt (AD 132-135), Oxford.

Applebaum, S. (1984), The Second Jewish Revolt (AD 131-135), Palestine Exploration Quartely 160: 35-41.

Ariel, Donald T. (1982), A Survey of Coin Finds in Jerusalem until the End of the Byzantine Period, Liber Annuus, Studii Biblici Franciscani 32: 273-326.

Avi-Yonah, M. (1954), Jerusalem - The Saga of the Holy City, Jerusalem.

Baker, R. (2012), Epiphanius, 'On Weights and Measures' §14: Hadrian's Journey to the East and the Rebuilding of Jerusalem, Zeitschrift für Papyrologie und Epigraphik 182: 157-167.

Barag, D. (1980), A Note on the Geographical Distribution of Bar-Kokhba Coins, Israel Numismatic Journal 4: 30-33.

Barag, D. (2002), The Two Mints of the Bar Kokhba War, Israel Numismatic Journal 14: 153-156.

Baras, Z., Safrai, S., Tsafrir, Y., Stern, M. (eds.) (1982), Eretz Israel from the Destruction of the Second Temple to the Muslim Conquest, Jerusalem (Hebrew).

Bazzana, G. B. (2010), The Bar Kokhba Revolt and Hadrian's Religious Policy, in: M. Rizzi (ed.), Hadrian and the Christians, Berlin-New York: 85-109.

Bellemore, J. (2003), Cassius Dio and the Chronology of A.D. 21, The Classical Quarterly 53: $268-285$.

Birley, A. R. (1997), Hadrian: The Restless Emperor, London.

Bowersock, G. (1980), A Roman Perspective of the Bar Kokhba War, in: W. S. Green (ed.), Approaches to Ancient Judaism, vol. 2, Missoula: 131-141.

Bowie, E. L. (2001), Inspiration and Aspiration: Date, Genre and Readership, in: S. E. Alcock, J. F. Cherry, J. Elsner (eds.), Pausanias: Travel and Memory in Roman Greece, Oxford: 21-32.

Buttrey, T. V. (1999), The Content and Meaning of Coin Hoards: Review of D. Backendorf (1998), Römische Münzschätze des zweiten und ersten Jahrhunderts v. Chr. vom italienischen Festland, Journal of Roman Archaeology 12: 526-532.

Capponi, L. (2010), Hadrian in Jerusalem and Alexandria in 117, Athenaeum 98: 489-501.

Costa, V. (2012), Ariston of Pella (201), BNJ.

Cotton, H. (2018/2019), Appendix: Hadrian: Rome and Jerusalem, Israel Museum Studies in Archaeology 9: 65-67.

Dąbrowa, E. (1998), The Governors of Roman Syria from Augustus to Septimius Severus, Bonn.

Deines, R. (2013), How Long? God's Revealed Schedule for Salvation and the Outbreak of Bar Kokhba Revolt, in: C. Ochs, P. Watts (eds.), Acts of God in History: Studies Towards Recovering a Theological Historiography, Tübingen: 191-225.

48.8.4.2), related to similar edicts of Domitian (Cassius Dio 67.2.3) and Nerva (Cassius Dio 68.2.4), but one still limited in its application. However, this issue is beyond the scope of this brief note to address. See Geiger 1976; Herr 1978, 8-9, note 41; Schäfer 1981b; Mor 2016, 129-135. 
Eck, W. (1982), Hadrian als pater patriae und die Verleihung des Augustatitels an Sabina, in: G. Wirth (ed.), Romanitas-Christianitas: Untersuchungen zur Geschichte und Literatur der römischen Kaiserzeit, Berlin: 217-229.

Eck, W. (1999), The Bar Kokhba Revolt: The Roman Point of View, The Journal of Roman Studies 89: 76-89.

Ecker, A., Cotton, H. (2018/2019), The Legio X Fretensis Welcomes the Emperor, Israel Museum Studies in Archaeology 9: 59-67.

Eliav, Y. Z. (1997), Hadrians Actions in the Jerusalem Temple Mount according to Cassius Dio and Xiphilini Manus, Jewish Studies Quarterly 4: 125-144.

Erlich, M. (2003), And Betar Was Caught and the City Plowed, Chidushim Be Cheker Jerusalem [Innovations in the Research of Jerusalem] 8: 111-116 (Hebrew).

Eshel, H. (1997), Aelia Capitolina: Jerusalem No More, Biblical Archaeology Review 23: 46-48, 73.

Eshel, H., Zissu, B. (eds.) (2001), Innovation in the Research of the Bar Kokhba Rebellion, Ramat Gan (Hebrew).

Eshel, H., Zissu, B. (2000/2002), Coins from the el-Jai Cave in Nahal Mikhmash (Wadi Suweinit), Israel Numismatic Journal 14: 168-175.

Fleischer, E. (1990), On the Antiquity of the Prayer in Israel, Tarbitz 59: 397-441 (Hebrew).

Geiger, J. (1976), The Ban on Circumcision and the Bar-Kokhba Rebellion, Zion 41: 139-147 (Hebrew).

Geiger, J. (2016), The Bar-Kokhba Revolt: The Greek Point of View, Historia 65: 497-519.

Geva, H. (1984), The Camp of the Tenth Legion in Jerusalem: An Archaeological Reconsideration, Israel Exploration Journal 34: 239-254.

Ginzburg, S. (1972), Was the Temple Built in the Days of Bar Kokhbah?, Sinai 36: 160-162 (Hebrew).

Gowing, A. (2016), Cassius Dio and the City of Rome, in: C. H. Lange, J. M. Madsen (eds.), Cassius Dio: Greek Intellectual and Roman Politician, Leiden-Boston: 117-136.

Gutschmid, A. von (1893), Kleine Schriften, vol. 4, Leipzig.

Habicht, C. (1985), Pausanias' Guide to Ancient Greece, Berkely-Los Angeles, CA.

Halfmann, H. (1986), Itinera principum. Geschichte und Typologie der Kaiserreisen im Römischen Reich, Stuttgart.

Herr, M. D. (1978), The Causes of the Bar-Kokhba War, Zion 43: 1-11 (Hebrew).

Isaac, B. (1983/1984), Cassius Dio on the Revolt of Bar Kokhba, Scripta Classica Israelica 7: 68-76.

Isaac, B., Oppenheimer, A. (1985), The Revolt of Bar Kokhba: Ideology and Modern Scholarship, Journal of Jewish Studies 36: 33-60.

Kanael, B. (1971), Notes on the Dates used during the Bar Kokhba Revolt, Israel Exploration Journal 21: $39-46$.

Kemezis, A. M. (2014), Greek Narratives of the Roman Empire under the Severans: Cassius Dio, Philostratus and Herodian, Cambridge.

Kindler, A. (1974), Coins of the Land of Israel: Collection of the Bank of Israel: A Catalogue, Jerusalem (Hebrew).

Kindler, A. (2000/2002), Was Aelia Capitolina Founded before or after the Outbreak of the Bar Kokhba War? A Numismatic Evidence, Israel Numismatic Journal 14: 176-179.

Labow, D. (2005), Flavius Josephus contra Apionem, Buch 1. Einleitung, Text, Textkritischer Apparat, Übersetzung und Kommentar, Stuttgart.

Lange, C. H., Madsen, J. M. (2016), Between History and Politics, in: C. H. Lange, J. M. Madsen (eds.), Cassius Dio: Greek Intellectual and Roman Politician, Leiden-Boston: 1-10.

Lapin, H. (1993), Palm Fronds and Citrons: Notes on Two Letters from Bar Kosiba's Administration, Hebrew Union College Annual 64: 111-135.

Levenson, D. B. (2004), The Ancient and Medieval Sources for the Emperor Julian's Attempt to Rebuild the Jerusalem Temple, Journal for the Study of Judaism 35: 409-460.

Lifshitz B. (1977), Jerusalem sous la domination romaine. Histoire de la ville depuis la conquête de Pompee jusqu'à Constantin, ANRW II 8: 444-489. 
Luria, B.-Z. (1972), The Temple during the Bar Kokhba Revolt, Beth Mikra 7: 70-84 (Hebrew).

Magness, J. (2011), Aelia Capitolina: A Review of Some Current Debates about Hadrianic Jerusalem, in: K. Galor, G. Avni (eds.), Unearthing Jerusalem: 150 Years of Archaeological Research in the Holy City, Winona Lake, IN: 313-324.

Mattingly, H. (1925), Some Historical Coins of Hadrian, The Journal of Roman Studies 15: 209-222.

Mattingly, H., Sydenham, E. A. (eds.) (1926), The Roman Imperial Coinage, vol. 2, London.

Meshorer, Y. (1967), Jewish Coins of the Second Temple Period, Tel Aviv.

Meshorer, Y. (1982), Ancient Jewish Coinage, New York.

Meshorer, Y. (1989), The Coinage of Aelia Capitolina, Tel Aviv.

Mildenberg, L. (1949), The Eleazar Coins of the Bar Kokhba Rebellion, Historia Judaica 11: 77-108.

Mildenberg, L. (1977), Bar Kochba in Jerusalem, Schweizer Munzenblatter 27: 1-6.

Mildenberg, L. (1980), Bar Kokhba Coins and Documents, Harvard Studies in Classical Philology 84: 311-335.

Mildenberg, L. (1984), The Coinage of the Bar Kokhha War, Aarau.

Mildenberg, L. (1998), Vestigia Leonis, Freiburg-Göttingen.

Millar, F. (1964), A Study of Cassius Dio, Oxford.

Mor, M. (1991), The Bar-Kokhba Revolt: Its Extent and Effect, Jerusalem (Hebrew).

Mor, M. (2012), Are There any New Factors Concerning the Bar-Kokhba Revolt?, Studia Antiqua et Archaeologica 18: 161-194.

Mor, M. (2016), The Second Jewish Revolt: The Bar Kokhba War, 132-136 CE, Leiden-Boston.

Oppenheimer, A. (1982), The Bar Kokhba Revolt, in: Z. Baras, S. Safrai, Y. Tsafrir, M. Stern (eds.) (1982), Eretz Israel from the Destruction of the Second Temple to the Muslim Conquest, Jerusalem: 40-74 (Hebrew).

Oppenheimer, A., Isaac, B. (1987), History of the Research of the Bar Kokhba Revolt, in: A. Kloner, Y. Tepper (eds.), The Hiding Complexes in the Judean Shephelah, Tel Aviv: 405-428 (Hebrew).

Petuchowski, J. J., Fleischer, E. (eds.) (1981), Studies in Aggadah, Targum and Jewish Liturgy, Jerusalem (Hebrew).

Pretzler, M. (2007), Pausanias: Travel Writing in Ancient Greece, London.

Pucci Ben Zeev, M. (2005), Diaspora Judasim in Turmoil, 116/117 CE: Ancient Sources and Modern Insights, Leuven.

Reifenberg, A. (1965), Ancient Jewish Coins, 4th ed., Jerusalem.

Ritti, T. (2004), Documenti Adrianei da Hierapolis di Frigia: Le epistole di Adriano alla città, in: S. Follet (ed.), L'Hellénisme d'époque romaine: Nouveaux documents, nouvelles approches (Ier s. a.C.IIIe s. p.C.). Actes du Colloque International à la memoire de Louis Robert, Paris, 7-8 Juillet 2000, Paris: $336-339$.

Rohden, P. von (1893), P. Aelius Hadrianus, RE I: 493-520.

Romanoff, P. (1971), Jewish Symbols on Ancient Jewish Coins, New York.

Safrai, S. (1980), The Pilgrimage to Jerusalem after the Destruction of the Second Temple, in: A. Oppenheimer et al. (eds.), Jerusalem in the Second Temple Period: Abraham Schalit Memorial Volume, Jerusalem: 376-393 (Hebrew).

Schäfer, P. (1981a), Der Bar-Kokhba Aufstand. Studien zum zweiten jüdischen Krieg gegen Rom, Tübingen.

Schäfer, P. (1981b), The Causes of the Bar Kokhba Revolt, in: J. J. Petuchowski, E. Fleischer (eds.), Studies in Aggadah, Targum and Jewish Liurgy, Jerusalem: 74-94.

Schäfer, P. (1990), Hadrian's Policy in Judaea and the Bar Kokhba Revolt: A Reassessment, in: P. R. Davies, R. T. White (eds.), A Tribute to Geza Vermes: Essays on Jewish and Christian Literature and History, Sheffield: 281-303.

Schürer, E. (1973), The History of the Jewish People in the Age of Jesus Christ (175 B.C.-A.D. 135), vol. 1, Edinburgh.

Sear, D. R. (2000), Greek Imperial Coins, 5th ed., London.

Shachar, Y. (2003), The Destruction of the Temple in the Vision of R. Akiva and the Forming of the Commemoration Fast, Zion 62: 145-165 (Hebrew). 
Smallwood, E. M. (1981), The Jews under Roman Rule, From Pompey to Diocletian: A Study in Political Relations, Leiden.

Stern, M. (1980), Greek and Latin Authors on Jews and Judaism, vol. II: From Tacitus to Simplicius, Jerusalem.

Swan, P. M. (2004), The Augustan Succession: An Historical Commentary on Cassius Dio's Roman History Books 55-56 (9 B.C.-A.D. 14), Oxford.

Syme, R. (1988), Journeys of Hadrian, Zeitschrift für Papyrologie und Epigraphik 73: 159-170.

Weksler-Bdolah, S. (2011), The Main Streets in Southeastern Jerusalem in the Roman Period and Their Role in the Development of Aelia Capitolina in the Second to Fourth Centuries CE, Focusing on the Excavations along the Eastern Colonnaded Street and the 'Wilson Bridge' ('Great Causeway'), unpublished Ph.D. diss., The Hebrew University of Jerusalem (Hebrew).

Weksler-Bdolah, S. (2014), The Foundation of Aelia Capitolina in Light of New Excavations along the Eastern Cardo, IEJ 64: 38-62.

Yadin, Y. (1971), Bar Kokhba, New York.

Zissu, B., Eshel, H. (red.) (2001), The Coins of the Bar Kokhba Revolt - Geographical Update: What Was Renewed in the Last Twenty Years (1980-2000), in: H. Eshel (ed.), Innovation in the Research of the Bar Kokhba Rebellion, Ramat Gan: 17-40 (Hebrew).

Zlotnik, Y. (2008), Coin Finds and the Question of the Conquest of Jerusalem by Bar Kokhba, Israel Numismatic Research 3: 137-146. 